\title{
I am/am I an African? A relational reading of Diaspora and Identity in South African Fiction by J.U. Jacobs
}

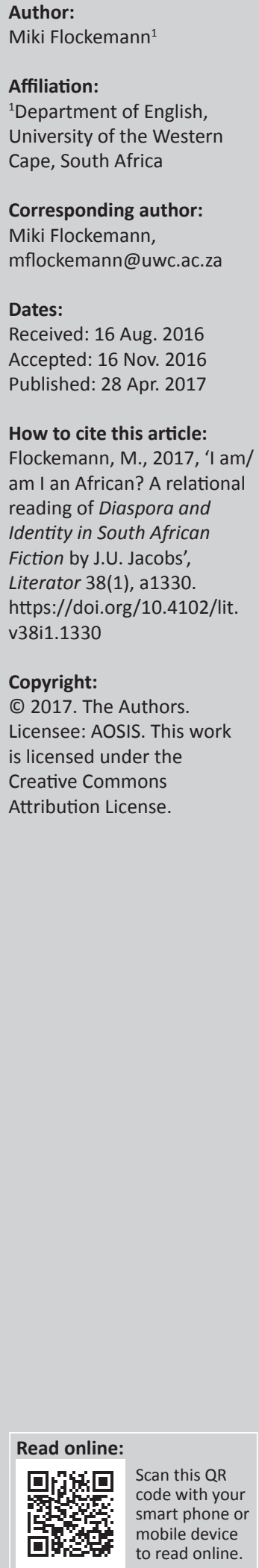

The publication of Diaspora and Identity in South African Fiction (2016) by J.U. Jacobs is a timely intervention, in that it is the first comprehensive study of South African fiction to sustain the argument that South African writing is always already diasporic. Although Jacobs' diasporic framework undoubtedly serves as an important addition to the recent trends identified by literary scholars, his focus on 12 well-established writers (including Coetzee, Wicomb, Mda, Gordimer and Ndebele), highlights some of the gaps that need to be filled in a study of this kind. For instance, what about the younger generation of writers, including those from elsewhere in Africa who are writing about living in South Africa? How do they deal with what has been termed the new diaspora, with debates around Afropolitanism and the experiences of internal, inter-continental and trans-continental migrancy in an increasingly globalising world? Despite these shortcomings, Jacobs' premise about the inevitably diasporic identifications that are narrativised in the 20 novels analysed here can provide a useful foundation for further scholarship on how the diasporic condition informs and is mediated in other texts. These, as I will show, range from works by a new generation of emerging writers on the one hand to the performing arts on the other hand.

Ek is/is ek 'n Afrikaan? 'n Relasionele lesing van Diaspora and Identity in South African Fiction deur Jacobs, J.U. Die verskyning van J.U. Jacobs se Diaspora and Identity in South African Fiction (2016) is besonder tydig aangesien dit die eerste samevattende studie van Suid-Afrikaanse fiksie is wat die standpunt handhaaf dat die Suid-Afrikaanse letterkunde uiteraard reeds diaspories is. Alhoewel Jacobs se diasporiese raamwerk sonder twyfel huidige tendense soos vasgestel deur letterkundiges op 'n noemenswaardige manier aanvul, bring sy fokus op twaalf goed gevestigde skrywers (onder andere Coetzee, Wicomb, Mda, Gordimer en Ndebele) sekere leemtes na vore wat deur 'n studie van dié aard gevul behoort te word. Byvoorbeeld, wat van skrywers van die jonger geslag, met inbegrip van diegene van ander Afrikalande wat skryf oor lewenservaringe in Suid-Afrika. Hoe hanteer hulle die kwessie van die nuwe diaspora, met debatte oor Afropolitanisme en ervaringe met interne, interkontinentale en tussenkontinentale migrasie in 'n wêreld met toenemende globalisering? Nieteenstaande hierdie tekortkominge kan Jacobs se standpunt ten opsigte van die onvermydelike diasporiese assosiasies, wat na vore kom in die twintig verhale wat hier ontleed word, 'n nuttige grondslag verskaf vir verdere studie oor hoe die diasporiese tendens op ander tekste inwerk en daardeur oorgedra word. Ek sal aandui hoe hierdie tekste wissel van werke deur 'n nuwe geslag opkomende skrywers, enersyds, tot die uitvoerende kunste, andersyds.

I was learning that human history is always a story of somebody's diaspora: a struggle between those who expel, repel or curtail - possess, divide and rule - and those who keep the flame alive from night to night, mouth to mouth, enlarging the world with each flick of a tongue. (Gunesekera 1996:174)

\section{Diaspora and the shaping of South African identities}

Given that the number of displaced persons has currently reached an all-time high, ${ }^{1}$ it is hardly surprising that globally diaspora studies have been proliferating across disciplines. Although there is no consensus on what diaspora entails, two broad interlocking streams have emerged, clustered around the transnational and the cultural aspects of diaspora experience. In addition, a shift from a focus on displacement and uprooting to connectivity and affiliation has been

1.According to a 2015 UNHRC report, global displacement is currently at its highest since the Second World War; while in 2014 the figure was 59.5, in 2015 it had reached 65.3 million people displaced as a result of wars and conflict. Global forced displacements hits record high, viewed 23 July 2016, from http://www.unhcr.org/news/latest/2016/6/5763b65a4/global-forced-displacementhits-record-high.html 
identified, from a 'fixation on homeland' to 'making one's home' ${ }^{2}$ This is a shift that can also be tracked in J.U. Jacobs' Diaspora and Identity in South African Fiction (2016).

The observation quoted above that 'human history is always a story of somebody's diaspora' captures the premise at the heart of Jacobs' book. He claims that South African writing has always been diasporic as a result of constant movements across the continent, first from North to South, then from South to North and back again. In mapping this argument, Jacobs begins by reading backwards through Sol Plaatje's Mhudi (1930) and concludes by looking forward through Njabulo Ndebele's The Cry of Winnie Mandela (2003). Approaching South African writing through a diasporic lens has gained some currency over the last two decades, but because this is generally employed in comparative studies with other diasporic texts from the Atlantic or Indian Ocean worlds ${ }^{3}$ or subsumed in the discourses of postcolonialism (Christian 2005:252-271; Rastogi 2008), Jacobs' monograph offers a useful intervention. Moreover, as outlined in the introductory chapter, this diasporic focus will undoubtedly provide a significant contribution to the cluster of literary trends which have been conceptualised by local scholars in often metaphoric terms of 'seams', 'entanglements', 'complicities' and 'transitivity'. ${ }^{4}$ However, the decision to structure the discussion around 12 well-established (even canonical) writers such as Breyten Breytenbach, J.M. Coetzee, Nadine Gordimer, Zoë Wicomb, Njabulo Ndebele and Zakes Mda, shows the shortcomings of such a project, shortcomings that Jacobs seems aware of, as indicated by the questions he poses in the introduction about the scope and ambit of his study. For example, despite the richly contextualised, detailed and insightful analysis of the 20 novels represented here, Diaspora and Identity in South African Fiction does not engage with what has been described as a 'new Africanicity' characterising recent fiction by a crop of younger writers (Smith in Fasselt 2015:232). Referring to the fact that all five novels shortlisted for the 2012 Sunday Times Fiction Prize featured characters from other parts of Africa, Tymon Smith (the books editor) describes this as 'a welcome new direction for local fiction that demonstrates the multitude of possibilities for looking not only within but beyond our geographical and psychological borders' (in Fasselt 2015:232).

The diasporic identities narrativised in Jacobs' study seem to be organised around thematic and historical contexts, rather

2.In her discussion of the "diasporic condition', Tsagarousianou claims that one should
see diasporic communities 'as imagined rather than given communities, that are constantly reconstructed and invented' (2004:52-65).

3.South African writers whose works have commonly been explored in comparative Black Atlantic and South East Asian diaspora frameworks include Bessie Head, Zoë Wicomb, Imraan Coovadia, Agnes Sam, Farida Karodia, K. Sello Duiker and Richard Rive, to mention a few. See, for example, Pinto (2013), Jamal and Moorthy (2010), Samuelson and Viljoen (2007), Raiskin (1996) and Nasta (1992).

4.The metaphor of the 'seam' is coined by Leon de Kok to describe an understanding of the way identities are formed across barriers and schisms, as a site of both difference and convergence (in Jacobs 3); Sarah Nuttall's use of the notion of 'entanglement' entails bringing together 'people and things' so that 'identitie "entanglement entails bringing together "people and things" so that identities spaces, histories - come together or find points of convergence in unexpected ways' (in Jacobs 3), while for Mark Sanders, recognising our complicity as a result of ou folded-togetherness is unavoidable. On the other hand, Stephen Clingman's formulation of transitivity, or of 'a transitive syntax of the self' which 'does not override or negate differences within the self or in relation to others - indeed depends on it' (in Jacobs 2016:5), perhaps most closely overlaps with Jacobs's description of diaspora identities. than grouping together texts and chapters that are aligned conceptually in terms of theoretical models of diaspora. (Jacobs does, however, stress that what links the texts is that they all share a diaspora consciousness. $)^{5}$ This seems a pity because the theoretical diaspora frameworks which are outlined so lucidly in the introductory chapter appear to invite one to read the narratives in relation to the conceptual affiliations offered here. However, the way the chapters are structured could be attributed to the fact that most are based on previously published stand-alone pieces which have been re-framed by identifying a specific diasporic vantage point as a point of departure for discussion of each author's work. This is evident to some extent in the chapter titles. For instance, the first five chapters give an indication of the different kinds of diasporas dealt with: 'The Colonial Diaspora: Karel Schoeman, Another Country' (Chapter 1); 'Portraits of Afrikaners: Elsa Joubert, Isobelle's Journey' (Chapter 2); 'Black and White in Colour: Zoë Wicomb, David's Story and Dancing in the Light' (Chapter 3); 'Mapping the Indian Diaspora: Azis Hassim, The Lotus People and Revenge of Kali' (Chapter 4); 'Picturing the African Diaspora: Patricia Schonstein Pinnock, Skyline' (Chapter 5). At the same time, despite the shortcomings mentioned above, Jacobs' premise does have additional value for scholars in the broader field of South African cultural production, in that it provides a foundation for exploring how the diasporic condition informs and is mediated in other texts. These range from works by a younger generation of emerging writers on the one hand to the performing arts on the other hand.

\section{Narrativising diaspora consciousness and diaspora space}

In framing this argument, I will first outline how Jacobs' selection of writers can be re-grouped to explicate key aspects of the diasporic condition which he identifies in relation to 'diaspora consciousness' and 'diaspora space' (about which more later). What emerges from this is a shift from works which perform and enact the interplay between locations of belonging and relocation (Karel Schoeman, Elsa Joubert and Azis Hassim) to those characterised by an acutely self-reflexive sense of unbelonging, of being a perpetual sojourner, not comfortable in one's own skin, imbricated in the burdened privilege of whiteness (Breyten Breytenbach, J.M. Coetzee). On the other hand, Zoë Wicomb's work can be read in relation to Stuart Hall's description of Caribbean diasporic identities where difference 'persists - in and alongside continuity' (in Jacobs 2016:51), as well as the notion of transitivity outlined by Stephen Clingman, where navigating identity involves exploration and transition (in Jacobs 2016:5). The notion of being unhomed in the postelection era as a result of back-and-forth travel which results in a profound unease informs his reading of Nadine Gordimer, Ivan Vladislavic and Michiel Heyns.

The most productive chapters for identifying synergies with other forms of cultural production are those which most 5.This is explained later. 
'thickly' demonstrate how the narrative aesthetic embeds a diaspora consciousness, manifested in what I will describe as the potentially future-directed works by Patricia Schonstein Pinnok, Zakes Mda and Njubulo Ndebele. However, this discussion needs to be expanded to include the growing body of emerging writers dealing with debates on Afropolitanism and the experiences of internal, intracontinental and cross-continental migrancy. The aim here is to show how the diasporic lens applied to the writers represented in Diaspora and Identity in South African Fiction can be read in relation to the way the diasporic condition is embedded in other forms of creative expression. Such a 'relational reading' of texts (even across genres) does not look for commonalities or differences associated with traditional comparative approaches; rather, it extends the interpretative frameworks for both works by reading them in relation to one another. By way of example, I will refer to some works presented at recent National Arts Festivals which perform (as live events before an audience situated as 'witnesses') the effects of diaspora consciousness resulting from migrancy from across the African continent as well as within South Africa. As Anton Krueger notes, performing migrancy has become so prevalent that it could 'become recognized as the emergence of a new theme in recent South African theatre' (2016:116). This is evident in works that range from local communities exploring how strangers in their midst from North Africa challenge their sense of South African belonging [as in Falling off the Horn (2016)] to those dealing with interactions between locals and migrants from neighbouring Southern African countries [such as Gina Schmuckler's The Line (2012) and Jonathan Nkala's The Crossing (2009)]. In addition, there is also a focus on internal migrations between Cape Town and the rural Eastern Cape, as well as along the route up the West Coast as far as Namibia, as represented by The Magnet Theatre 'Migration' Plays (2012).

But first, it is necessary to return to a more detailed examination of the premises at the heart of Diaspora and Identity in South African Fiction. For instance, Jacobs' choice of Sol Plaatje's novel Mhudi as exemplifying the legacy of migratory flows from pre-colonial times onwards deliberately shifts the diasporic nexus away from the familiar Western or European imperial axis to focus also on intra-continental migrations. He claims that Plaatje's novel shows that diaspora 'was the crucible for the formation of modern African identities'. At the same time, these identities are still shaped by negotiating tensions between 'the dream of home and its associations of belonging and of ethnic and cultural cohesion', but also 'the reality of division, engagement and entanglement with the other' (p. 12). ${ }^{6}$

It follows that the inbetweenness of diaspora experience is key here. ${ }^{7}$ The introduction maps the basic tenets of diaspora studies by explicating the work of some of the most prominent

6.Jacobs draws here on a study by Annalisa Oboe "From South Africa to Europe to North America and Back: Sol Plaatje, W.E. Du Bois, and the routes of Romance (Jacobs 2016:7-11).

7.As lan Chambers notes: 'living between worlds, identities are formed across frontiers that pervade every aspect of their being' (in Jacobs 2016:24). diaspora scholars. Apart from identifying the diaspora experience geographically and historically, Jacobs outlines concepts such as 'diaspora consciousness' and 'diaspora space' which inform his readings of the novels, and explains that his primary concern is to examine the way in which fictional accounts narrativise and perform or enact diaspora consciousness. Diaspora consciousness (as described by Aisha Kahn) is a sensibility 'that marks the very act of uprooting as shaping their sense of self and that memorialises displacement in everyday discourse and practice' (in Jacobs 2016:25). On the other hand, as a conceptual category, diaspora space (as defined by Amitav Brah) is 'inhabited not only by those who migrated and their descendants, but equally by those who are constructed as indigenous' (in Jacobs 2016:26). Brah distinguishes between diaspora and diaspora space, claiming that diaspora space 'includes the entanglement, the intertwining of the genealogies of dispersion, with those of staying put' (in Jacobs 2016:26). These two concepts outlined by Kahn and Brah serve as the point of departure for Jacobs' nuanced analysis of the aesthetic strategies employed in narrativising the processes of (occasionally laborious) self-reflexive identity construction. In each of the texts selected, Jacobs teases out how these narratives embody, enact or perform the apparent disjuncture between 'uprooting' and 'shaping' on the one hand, as well as the interlocking inbetweeness of 'dispersion' with 'staying put' on the other hand.

As noted earlier, what is missing from the study is an account of diaspora consciousness as explored by perhaps less wellknown or younger writers. Jacobs' introductory chapter could, in fact, serve as a useful stand-alone foundation for a discussion of South African writers dealing with migrant experiences from diverse perspectives (such as Imram Coovadia's The Wedding, Moele Kgebetli's Room 207 (2006), Phaswane Mpe's Welcome to our Hillbrow (2001), Angelina N. Sithebe's Holy Hill (2007) and Meg Vandermerve's Zebra Crossing (2013), to mention a few). ${ }^{8}$ This should, however, also include writers from elsewhere on the continent who live in, and write about, South Africa. Rebecca Fasselt claims that these voices 'are invaluable, bringing into the public sphere different and more nuanced narratives of African immigrants and refugees' (2015:232). For example, Yewande Omotoso draws on her own West Indian and Yoruba heritage (her mother was from Barbados, and her father is Nigerian), to explore local spaces and people in Cape Town in her debut novel Bom Boy (2011). In a conversation with Fasselt, Omotoso explains that although the term Afropolitan has been used to describe individuals like herself who travel frequently, managing to negotiate diverse cultural milieus, and who seem to be at home in several countries and contexts, she, nevertheless, rejects the label. Noting that Afropolitanism privileges the relationship between Africa and the West, and is associated with an educated and 'elite' class embarking on

8.Fasselt (2015) provides a comprehensive list of South African novels which incorporate African migrant characters, or which deal with xenophobia following the attacks on 'foreign' fellow Africans; in addition to those referred to above, she includes, amongst others, Nic Mhlongo's Dog Eat Dog (2004), K. Sello Duiker's includes, amongst others, Nic Mhlongo's Dog Eat Dog (2004), K. Sello Duiker's
Thirteen Cents (2000), Jonathan Morgan's Finding Mr Mandini (2009), Andrew Brown's Coldsleep Lullaby. 
voluntary rather than coerced migration, Omotoso claims that she is 'of the continent' and that 'the story of the nonSouthern African in South Africa would be a different narrative' (in Fasselt 2015:235). Speaking of her latest novel, The Woman Next Door (2015), Omotoso stresses that her diaspora consciousness is shaped by a sense of connectedness, of affiliation; as she puts it, her storytelling privileges the micro, in order to show connections, to 'see ourselves in others' (Omotoso 2015).

In the early chapters of Diaspora and Identity in South African Fiction featuring Karel Schoeman, Elsa Joubert and Aziz Hassim, diaspora features primarily in terms of thematic motifs involving the interplay between locations of belonging and relocation; in each case, Jacobs provides carefully historicised contexts to these migrations from Europe and within Southern Africa, as well as the movements of peoples from South East Asia, ranging from the era of slavery at the Cape to the transportation of indentured labour to Natal, and then as 'free' economic migrants engaged in what has been described as the 'new diaspora'. Schoeman's Another Country (1991), set in 19th century colonial Bloemfontein, is read through the operation of cultural memory as a fluid reconstruction of a remembered rather than a factual past. On the other hand, drawing on Hall's discussion of the interplay between 'being' and 'becoming' intrinsic to diaspora experience, Jacobs shows how Joubert's Isobelle's Journey (2002) tracks the evolution of Afrikaner identity emerging from a dialogic relationship between continuity and discontinuity. Hassim's The Lotus People (2002) and Revenge of Kali (2009) are read in relation to narratives of loss created by the figurative mapping of physical, imaginary and interpersonal spaces as a consequence of diversely motivated migratory flows. Such migrations are succinctly contextualised as impelled by 'desperation' or the 'dollar', and alternatively in terms of class, as the 'brawn drain' as opposed to the 'brain drain'. As Brij V. Lal explains, there are diasporas within diasporas: 'the "dollar" diaspora of the West and the "desperate" diaspora in the developing world, those which were formed by the "brawn drain" and those by the "brain" drain' (in Jacobs 2016:98). Here it would have been interesting to include discussion of some younger writers like Imram Coovadia whose novels, which have also been interpreted within diaspora frameworks, can offer additional perspectives on articulations of 'new' (Indian) diasporic identities (Frenkel 2010).

Of these three chapters, the most instructive is Jacobs' discussion of the complex 'speech world' of the colonial diaspora created in Schoeman's Another Country. By unpacking the linguistic nuances of the focalising consciousness of the unhomed Versluis, as it simultaneously distances and identifies, Jacobs (2016) demonstrates how code-switching performs both the 'disaggregated identity' of the migrant referred to by Daniel and Jonathan Bayarin and the 'new way of speaking' typical of 'the diasporic drama of displacement' (pp. 43-44). Here Jacobs offers a deeply engaged analysis of how 'the transitivity of the diaspora subject' (p. 44) is enacted within the narrating consciousness in tandem with the gradual coming into being of a new consciousness.
Another aspect of diaspora characterising South African fiction is the self-reflexive sense of unease and unbelonging enacted through constant back-and-forth travel between the local home and the one situated 'elsewhere'. For some there is also the sense of being a perpetual sojourner, not comfortable in one's own skin. At the same time, this sense of unbelonging is often the ongoing legacy of apartheid, imbricated in notions of whiteness. Commonly, these narratives are not about the diasporas of marginalised communities or as a result of forced removals of indigenous inhabitants, but about a self-imposed exile. In turn, this search for a new or a better place 'to be' often results in a restlessly entropic and endless inbetweenness. The chapters which could be read along these lines include those on Breyten Breytenbach, J.M. Coetzee, Nadine Gordimer, Ivan Vladislavic and Michiel Heyns.

At the same time, the diaspora consciousness enacted in Zoë Wicomb's novels has some commonalities with the works by the writers I have loosely grouped together in the previous paragraph. However, as Jacobs notes, in David's Story (2000) and Playing in the Light (2006), 'staying put' is complicated by the entanglements of dislocated migrants within an indigenous belonging. As mentioned earlier, each writer's work is contextualised and read through a particular diasporic framework, and in the case of Wicomb, Jacobs focuses on the textual strategies employed which locate coloured identity within diaspora space through the intertwining and contrary pulls of the 'genealogies of dispersion with those of "staying put"' (Brah in Jacobs 2016:79). Further quoting Brah, he explains that the diaspora space (where 'colouredness' is located), is where diaspora, location and dislocation intersect, and 'where multiple subject positions are juxtaposed, contested, proclaimed and disavowed' (in Jacobs 2016:79). It is a pity that Jacobs does not include a more extended discussion of her latest novel, October (2014), because it speaks so strongly and precisely about this intersection between diaspora, location and dislocation. As we have seen, in contextualising his reading of Joubert's Isobelle's Journey, he draws on the preoccupation of Caribbean writers with the experience of 'difference within identity' resulting from diverse colonial encounters superimposed upon the initial dislocations resulting from the transatlantic slave trade. However, the experience of 'difference within identity' in relation to the complexities of a colour-coded class hierarchy which underpins the work of many Caribbean writers for me resonates more directly with Wicomb's work than with Joubert's. This suggests a potentially productive additional frame for reading Wicomb's novels which is borne out by the plethora of comparative studies that read Wicomb in relation to other writers from the Black Atlantic diaspora, including writers from North America like Toni Morrison, Paule Marshall (born in Barbados) and Jamaican-born Michelle Cliff. For instance, Michelle Cliff claims about Wicomb: 'she speaks for me, another 'Coloured' from another end of Empire'; this points to synergies between the notion of 'difference within identity' and colouredness as located within diaspora space articulated 
in Wicomb's work, as well as notions of creole subjectivity that are commonly explored by writers from the Caribbean. (Cliff notes that when she is in the United States, she describes herself as a black feminist, but when she is back in Jamaica, she is seen as a white creole of mixed descent.) $)^{9}$

Brah's comments on the multiple subject positions of diaspora space are of course also pertinent to the selfreflexivity of Breytenbach and Coetzee. Jacobs reads Breytenbach's A Veil of Footsteps (Memoir of a Nomadic Fictional Character) (2008), through his notion of 'The Middle World' inhabited by noncitizens, where the nomad or mongrel or bastard as Breytenbach describes himself, senses that he has 'fatally lost the place [he] might have wanted to run back to' (in Jacobs 2016:158). Using writerly masks to show that 'all of us live behind projections of ourselves' (in Jacobs 2016:163), he writes himself in and out of exile; for Breytenbach, writing involves both self-creation and destruction. Similarly, Jacobs illustrates how Coetzee in his autobiographical (or autrebiographical) works [from Boyhood (1997) and Youth (2002) to Slow Man (2005) and Summertime (2009)] employs the third person and present tense to create a distancing effect, establishing a disjuncture between the narrating voice and the narrative consciousness. The provisionality of this technique foregrounds 'a certain style of mind' (Jacobs 2016:232), longing to belong, while at the same time positioning himself as a sojourner, an uneasy guest, uncomfortable in his own skin. Jacobs' sensitivity to the linguistic registers and voices employed here (as in the chapter on Schoeman) is impressive in the way it demonstrates the everyday 'practices' of unbelonging, caught up in a constant state of deferral and referral.

The focus on notions of home as an illusion of coherence is central to the chapter on Nadine Gordimer's None to Accompany Me, The Pickup and No Time Like the Present (this is another case in point where it would be productive to read Gordimer's texts in relation to those produced by a younger generation of writers referred to earlier, such as Mpe and Duiker, for example). Jacobs reads this preoccupation with home in relation to Gordimer's appropriation of the concept of the Interregnum, where one identity is discarded while a new one is still to come, resulting in a state of 'unhomeliness'. As Jacobs points out, Bhabha's definition of being unhomed in terms of finding oneself suddenly 'taking the measure of your dwelling' in a state of profound unease (in Jacobs 2016:265), speaks to the sense of the liminality associated with 'dwelling' in the newly democratic country explored in Gordimer's fiction, where, 'uncannily borders between private and public become part of each other', causing a sense of disorientation as one experiences an 'estranging sense of the relocation of the home and the world' (Bhabha in Jacobs 2016:265). On the other hand, the chapter on Vladislavic and Heyns tracks the out-and-in migratory trajectories of 'homecoming', and Said's description of the (in this case

9. Michelle Cliff says that Wicomb's comments on finding her voice as writer resonate with her own 'diasporic condition' as woman (in Cliff 1991:66). See also Raiskin
$(1996: 205-33)$, Flockemann (2001:116-133), Kaarsholm (2012:454-466), Richards (2002:20-33). self-imposed) exiled subject who exists 'in a medium state, neither at one with the new setting nor disencumbered of the old' (Jacobs 2016:239) has echoes of Gordimer's Interregnum. This is expressed through the gradual 'loosening' of the selfprotective irony in Heyns' narrator in Lost Ground (2011) as he comes to 'take the measure of his dwelling'. Central to Jacobs' discussion of Vladislavic's Double Negative, first published together with a sleeved set of David Goldblatt's TJ: Johannesburg Photographs 1948-2010 (2010), is the notion of the epiphyte (the global citizen treading lightly on the earth, unrooted), as well as the concept of ekphrasis (where a painting or visual artwork is described in literary terms). Jacobs summarises ekphrasis, as 'one art form speaking through another' (Mukherjee in Jacobs 2016:243). The aim, Vladislavic explains in an interview, is to create a field of references to the photographs ... and in so doing generate in the reader a certain discomfort' (in Jacobs 2016:244). This discomfort arises as a result of what Vladislavic describes as 'a kind of magnetism between the novel and the photographs, where reading passages of the novel triggers memories of the photographs you have seen' (in Jacobs 2016:144). However, according to Stephen Clingman, what matters in this process is 'what occurs in the spaces, both within the two works and between them' (in Jacobs 2016:244).

As noted earlier, the most productive discussions are those demonstrating how the narrative aesthetic embeds a diasporic consciousness within potentially future-directed works. In addition, the chapters on Schonstein Pinnok, Zakes Mda and the concluding chapter on Njabulo Ndebele's Cry of Winnie Mandela, explore alternative diaspora frameworks to those presented so far. These are grouped together here as they offer possibilities for the innovative newness associated with diaspora experience, and look forward as much as looking backwards, to posit potentially creolised processes of subject formation. Similarly to Vladislavic's first edition of Double Negative which includes Goldlatt's photographs to be read alongside the text, Pinnok's Skyline (2000), which deals with the intra-Africa diaspora, incorporates paintings as integral to the narrative structure by juxtaposing text and image to frame different migrant experiences in Cape Town. In his illuminating discussion of ekphrasis in Pinnok's novel, Jacobs presents a useful exposition of the term and (from Mitchell) shows how this juxtaposition creates a dialectic between the 'sayable' and the 'seeable' (in Jacobs 2016:141). The effect of this strategy, notes Jacobs (2016), is that:

image and text merge to convey what it means collectively and individually to experience the African diaspora, to attempt to depict the overlapping histories of conflict and dislocation and to write about it from a South African perspective. (p. 141)

Jacobs' nuanced discussion of the metafictional and intertextual cross-referencing evoked in the final painting suggests how aesthetic hybridity points to the potential for hybridised diasporic subjectivities.

The chapter on Mda's Sometimes there is a Void (2011) and Cion (2007), by being sandwiched between those on Breytenbach 
and Coetzee, emphasises the 'difference' between writerly migratory experiences, because all three establish 'a dialogue between autobiography and fiction' (p. 179). I was struck by Mda's quite pragmatic and even prosaic account of his sense of outsiderness and the 'void' of belonging resulting from his initially politically driven, rather than self-imposed exile (first to Lesotho, and later in the United States), when read against the more painfully self-reflexive accounts of Breytenbach's and Coetzee's self-exiles (which in turn can be read relation to imbricated notions of whiteness as a burden). At the same time, Mda's autobiographical account of absence is counterpointed by the diasporic exuberance of Cion, with its reincarnation of the professional mourner, Toloki, from his first novel, Ways of Dying. The self-reflexive interaction between the sciolist (Mda) and the cion (Toloki) offers a dialogic account of the relationship between Africa and the African American diaspora (described as 'a cultural offshoot and its roots') (in Jacobs 2016:192).

The 'newness' or innovation alluded to above is captured in the account of the patchwork quilting process practised by the family of diasporic origins that Toloki encounters on his travels to the United States. Against her mother's insistence that only traditional ancestral African patterns must be used in the quilt, the daughter insists: 'I want to invent patterns that tell my own story' (in Jacobs 2016:198); she does this by inserting everyday materials, adding beads, appliquéing bits of cloth, sewing on collages and found objects. In the course of the novel, the mother eventually accepts her daughter's 'playing' with tradition and as Toloki observes, 'her hybrid art must express her own present reality' (in Jacobs 2016:198). Similarly, Toloki transforms his own mourning performance as a result of his encounter with the daughter's innovative musical riffs on oral storytelling performances that can be traced back to the legendary ancestral Abyssinian Queen. Although Toloki or Mda might refer to these as hybridised performances, I prefer to see these as creolised or 'new ways of speaking', generated by the 'diasporic drama of displacement' noted earlier (Bayarin in Jacobs 2016:44). After all, by incorporating Toloki's own self-invented mourning performances into the daughter's soundscapes which draw on traditional call and response forms, an innovative mourning ritual is created which is not just a hybrid of different forms, but as Toloki says, transports them 'to another place; another realm; another time' (Jacobs 2016:200). Jacobs' (2016) concluding assessment of Mda's novel as diasporic text needs to be quoted in full, because it looks forward to his commentary on Ndebele's The Cry of Winnie Mandela, but also passes commentary on the works discussed so far. The remark on ventriloquism, for instance, points to the writerly masks employed by Breytenbach and Coetzee:

The final lessons of Mda's novel are that a diasporic culture must eventually free itself from the constraints of ancestral culture and, together with this, that diaspora is best served not by a text that is the product of a traditional, omnipotent author living vicariously and ventriloquising through his fictional characters, but by one that is embedded in and performs the complexities and contradictions of the diasporic identities it mediates. (p. 203)
The diasporic lens that Jacobs applies to Ndebele's novel in the final chapter, 'Embracing Chaos', takes the discussion of diaspora consciousness and space in yet another new direction, that of chaos theory; in other words, reading diaspora as chaos. Here Jacobs draws on Minoli Salgado's argument that 'the fundamental principle of chaos, that of generative disorder, lies at the unstable core of the diaspora experience' (original emphasis, in Jacobs 2016:297). ${ }^{10}$ The Cry of Winnie Mandela engages with Ndebele's preoccupation with 'the paradoxical characters of a newly liberated country ... that is apparently so divided and self-destructive' (in Jacobs 2016:291). In framing his account of how four women who represent 'the life at the centre of the great South African story not yet told' experience migration as 'waiting wife' rather than as 'the wanderer' (in Jacobs 2016:292), Ndebele includes the story of Sara Baartman as symbolic of African diasporic experience. In the process, he charts an account of the different forms of South African migration, from labour diasporas to the political and 'new' diasporas by young professionals. Jacobs reads Ndebele's description of overlapping diasporas in the history of black South Africans (including internal exile) which have caused such 'sustained and unbearable psychological turbulence' as 'chaotic' (Jacobs 2016:290). This speaks to Salgado's description of how systematic and generative chaos 'lies at the unstable core of diaspora experience' (in Jacobs 2016:297). In view of the way home is experienced as displacement, says the storyteller Marara (who speaks of, and for, Winnie Mandela), 'home temporally becomes the shared experience of homelessness, the shared feeling of loss and the desperate need to regain something' (Jacobs 2016:303). The chaotic trauma of homelessness and loss underlies the account of Winnie's duality - which veers between regality and gangsterism. What does this say about our national identity? Marara asks: 'Have dislocation and contradiction become part of the structures of thinking and feeling that may define our character?' (Jacobs 2016:304). Marara sees the deliberate embrace of uncertainty and contradiction as essential to 'where the vitality of our newness and creativity lies', but questions whether this is possible 'without homes wherein individuals can flourish through histories of intimacy' (Jacobs 2016:304).

The decision to conclude the book with Ndebele's novel seems fitting at one level because it perhaps most directly addresses the issues of diaspora, homelessness and points to the way forward in relation to the shaping of identity. However, where does this leave the questions Jacobs raised at the beginning of the study about the scope of his project. These include general questions about the appropriateness and capacity of the term diaspora to describe the diverse migratory experiences discussed, including that of colonial migration. For instance, he ponders whether the contemporary migrations described by Azis Hassim should be read as a second stage of the Indian diaspora, or as also forming part of the present-day (South) African diaspora (one could argue that Imram Coovadia's writing, for instance, would be seen

10.According to Minoli, 'the structural and ideological paradigms of chaotics' are useful to understanding modern migration and 'to formulate an appropriate critical language for the cultural conditions it creates' (in Jacobs 2016:297). 
in terms of the latter). Jacobs' question about African migrants is telling: he asks, 'how legitimate is it to include all African migrants, often from very diverse national backgrounds and historical experiences, in the homogenising/panAfricanist concept of an African diaspora?' (Jacobs 2016:20). He also asks, 'should one rather think in terms of an intra-African diaspora?' (Jacobs 2016:20). Here, Yewande Omotoso's critique of Afropolotanism discussed earlier would have been pertinent, and it is a pity that Jacobs does not revisit these questions at the end of his study, as one is left feeling that these are largely left unanswered.

Nevertheless, as previously suggested, given the range of texts and writers and the depth of scholarship involved, Jacobs' book will nevertheless serve as an important foundational text for 'reading diasporically' from the 19th century to the present. Although very readable, the work is scrupulously and widely cross-referenced. (I found myself reading the endnotes with interest in their own right as it were, rather than just for clarification) The inclusion of fairly extensive quotations from the fictions themselves gives the reader a good sense of each writer's own voice. As noted, the chapters on Mda, Pinnock and Ndebele point to more futuredirected diaspora frameworks where the tension between 'being and becoming' is inflected by 'making', in the sense of an action, whether of the imagination or material creation, as in the paintings in Skyline or the patchwork quilts and creolised performances of Toloki in Cion. This is in keeping with the shift to diasporic connectivity rather than 'lost' homeland referred to earlier. Jacobs' summation of Ndebele's project suggests the potential for further scholarship pointed to earlier on ways of approaching works by perhaps less well-known or younger writers.

For a truly new and ethical South African homecoming, his novel suggests, South Africans would have to identify themselves with the chaotic trajectories of their diasporic histories, to acknowledge division and embrace difference. This would require reconciliation, not of these differences and divisions, but with the fact of a national identity defined in terms of them. (Jacobs 2016:311)

The connections that Ndebele makes between diasporic unhomeliness and the self-destructive violence so endemic to South Africa are interesting when compared to Breytenbach's and Coetzee's painstakingly expressed disappointment, and even disgust, because for Ndebele it seems an injunction to face up to the why and to chart a way forward by 'embracing difference'. In fact, it is telling how pervasively this concern appears across a range of different local forms of creative expression, and this speaks to Jacobs' thesis about the diasporic undercurrent in South African fiction. At the same time, in exploring some of these other forms of creative expression in this next section, I will attempt to engage with the questions that Jacobs raises in his introduction, such as whether diverse fictional subjects (such as J.M. Coetzee and Winnie Mandela) can be connected under the common rubric of diaspora, as well as whether contemporary African political refugees and the new diaspora of African economic émigrés constitute an ongoing African diaspora (Jacobs 2016:20).

\section{Performing diaspora and identity}

For instance, it was striking how many works at the annual National Arts Festival in Grahamstown this year (2016) engaged implicitly or explicitly with notions of South African identities in terms of belonging and migrancy, locally and across Africa. These ranged from a satirically dystopian riff on then-President Thabo Mbeki's celebratory and idealistically inclusive inaugural presidential address, 'I am an African' (which at the time exemplified acknowledgement of division and the embrace of difference in forging an imagined South African national identity) to Falling off the Horn, a visual theatre production by a local communitybased group responding to recent xenophobic attacks on Somalian shopkeepers in Grahamstown. As Paul White notes, imaginative texts present an ideal vehicle for exploring the experience of migrancy because migrants live in multiple worlds which entail negotiation and constant self-refashioning (White 1995:6). It is thus hardly surprising that performing the experience of migrancy has gained increasing traction at recent National Arts Festivals. After all, as live events, these performances create a virtual contact zone between performers enacting the experiences of migrancy, and spectators who are situated as 'witnesses' to these events. The focus of performing migrancy extends from the everyday trauma of an ongoing sense of being 'unhomed' as a result of internal migrancy (a legacy of the apartheid migrant labour system) to encounters between unwilling South African 'hosts' and migrant 'strangers' from elsewhere in Africa. These encounters reveal how the hosts' own sense of their South African identity is challenged by encounters with fellow African 'strangers'. An excellent example of productions which cover this wide range of migrant experiences is Magnet Theatre's collection, The Magnet Theatre 'Migration' Plays (2012), because the four productions (three of which have also been performed at several National Arts Festivals) track a number of migratory routes within and beyond South Africa. For instance, the two works set along the N2 between the Western and Eastern Cape are performed in an incantatory isiXhosa with cryptic English surtitles projected onto a cowhide screen, whereas the work set along the N1 stretching up the West Coast as far as the Namibian border is a cautionary tale (in regional dialects of Afrikaans), which explicates how a local sense of literally circumscribed and fenced-off South African belonging is threatened when a small-town community encounters a 'stranger' found living amongst them. ${ }^{11}$ The first play in the collection, Every Year, Every Day, I am Walking, which is the most frequently performed of their plays, tracks the journey of a mother and daughter's arrival in Cape Town after fleeing their war-torn country in Francophone Africa. The reactions of locals to them when they finally reach the mother city foregrounds the ironies of South African identities based on exclusion, rather than the sense of connectedness, of seeing the self in the other, such as associated with the kind of inclusive panAfrican diaspora experience referred to by Yewanda Omotoso.

11.The two plays exploring migrancy along the $\mathrm{N} 2$ are ingwaba lendoda lise ndlela [the grave of the man is next to the road) and Inxeba Lomphilisi (The Wound of a Healer) (both directed by Mandla Mbothwe). The play set along the N1 is Die Vreemdeling (The Stranger). 
Needless to say, the 2008 xenophobic attacks have featured strongly in performances dealing with the experiences of migrancy, such as Gina Schmuckler's verbatim piece, The Line (2012), which draws on unedited interviews with perpetrators, victim-survivors and witnesses to the attacks which began in Alexandra township in Johannesburg. Particularly shocking is the fact that the 'foreigners' who were targeted were in fact neighbours, living in next-door shacks, who were from bordering Southern African states like Mozambique; in fact, sometimes Zulu speaking, not 'strangers' at all. A similar focus on how the 'proximity' of a fellow African neighbour or stranger threatens marginalised South Africans is evident in Jonathan Nkala's The Crossing based on Nkala's own experiences of jumping the border from Zimbabwe to South Africa. The play is the final work in a trilogy, tellingly titled Cockroach, pointing to the derogatory common-held notion of foreigners as hardly human ${ }^{12}$ (also evident in the interviews performed in The Line). In addition, a growing body of theatre scholarship has been generated by performances dealing with migrancy, such as, for instance, a collection edited by Mark Fleishman, Performing Migrancy and Mobility in Africa: The Cape of Flows (2015), while another compilation which focuses on South-South migration within Africa is in process. ${ }^{13}$

The two works referred to at this year's Festival thus need to be seen in relation to a growing body of works and scholarship on performing migrancy within, beyond and to South Africa. For instance, in his satirical revue, Pay Back the Curry! Mike Van Graan juxtaposes extracts from Mbeki's incantatory delivery of his famous 'I am an African' soliloquy with the voice of a Zimbabwean living in South Africa to highlight the failure of such claims to a diasporic South African national identity. Here are the opening lines from Mbeki's speech, followed by those of the Zimbabwean performer:

I am an African
I owe my being to the hills and valleys

The mountains and the glades

The rivers, the deserts, the trees and the

Ever-changing seasons that define the face of my native continent

From which I would flee if I had the means

Am thinking of fleeing

Have now fled. (Van Graan 2016:15) ${ }^{14}$

Although Mbeki's speech romanticises the 'diasporic crucible' shaping modern South African identities (as referred to in relation to Plaatje's Mhudi), the Zimbabwean's response here paints a dire picture of the current African diaspora and points to South African exceptionalism in relation to fellow Africans referred to earlier. On the other hand, one could argue that Falling off the Horn ${ }^{15}$ gives another slant to Amtiav

12.For a more detailed account see Flockemann et al. (2010).

13.Seasons of Migration to the South: Literatures of Intra-African Migration, edited by Rebecca Fasselt \& Aghogho Akpome, to be published with the Routledge series Literature of the Global South.

14.The script is by well-known playwright and cultural activist, Mike van Graan directed by Rob Van Vuren and performed by Daniel Mpilo Richards. Quoted with permission of the author.

15.Falling off the Horn is performed by a Grahamstown-based company, Uyabona Ke, which means 'See what I mean'. It was directed by Sam Pennington and performed by Khaya Kondiile, Nombasa Ngoqo, Mziwanele Jodwana and Ayanda Nondlwana.
Brah's description of diaspora space as entangled by both migrant and indigenous inhabitants. The performers use mime and sculpted full face masks as a simple storytelling device to make meaning of the experiences of, and local attitudes to, intra-African migrancy following the recent attacks on Somalian migrants in their community. The stage design and performance aesthetic employed physical gesture, embodied images and sound to explore the everyday intimacies involved in inhabiting diaspora space. This was played out in the virtual reality of the diasporic contact zone provided by the performance space.

For instance, in a parodic scene, the Somalian refugee, who has fled his homeland to find a new home in South Africa, attempts to claim his right to sit on a public bench, only to have a series of local 'types' attempting to lay their (apparently autochthonous) claim as the same bench as 'belonging' to them, which results in much shifting, shuffling, elbowing, as the tilting bench becomes (literally) an unstable and contested space. The apparently multivalent public bench is juxtaposed against a rudimentary structure behind it, representing the private, domestic sphere. This begins as the home of a local woman and her daughter who initially welcome the stranger into their home and then transmutes into one-half being her spaza shop, which is then challenged by his (cut-price) other half spaza shop opening on the adjoining side. He moves from the homelessness of sleeping on the public bench to making the house his home where he lives with the woman's daughter who becomes his wife, until he is attacked by a mob incited by the same woman and forced to flee. Not only does visual theatre involve 'listening with your eyes', ${ }^{16}$ but in this case the soundscape invites 'seeing with your ears' when the stranger's attempts to make a home for himself on the bench is accompanied by the soundtrack of Ladysmith Black Mambazo's Homeless, which encapsulates the longing for the rural home experienced by South African migrant workers, and points to connections with the Somalian refugee's situation, despite his outsider status. One could see the isicathamiya-style singing produced by the composer and leader of Ladysmith Black Mambazo, Joseph Shabalala, as an example of a musical creolisation because it is both a popular form, which as Christopher Ballentine notes, 'has roots that powerfully connect it to older Zulu musical and dance traditions - some of them of pre-colonial provenance' (2000:233), while also being 'new' in the way his lyrics and music are shaped by the imaginary choir that Shabalala hears in his dreams. At the same time, it has absorbed 'traces of such other idioms as American minstrelsy, vaudeville spirituals, missionary hymnody, Tin Pan Alley, Hollywood tap dance and gospel music' (Ballentine 2000:233). ${ }^{17}$ Using this diasporic musical counterpoint to the story of the Somalian refugee enables local audiences to 'see' and 'hear' the diasporic condition of being both connected and

16. Rob Murray, who is well-known for his innovative visual theatre productions, and has also worked with the cast of Uyabona Ke, used the slogan 'Listen With Your Eyes' for his former visual theatre company (FTH:K) which also included hearingEyes for his former
impaired actors.

17.As Christopher Ballantine (2000:234) points out in an ethnographic study of Shabalala's compositions, isicathamiya, is 'still predominantly the domain of migrant worker's hostels and their all-night isicathamiya competitions'. 
experiencing the 'difference within identity'. This occurs several times in the play when music infused with local resonances (or connections) of belonging, home and homelessness is used as an ironic subtext for the refugee's sense of exclusion from his fellow African community. The play ends with the actors, now without their masks, toyitoying and chanting protests against foreigners in their midst, which as it were jolts the spectators into the present, while the voice-over of Thabo Mbeki's assurances in 2008 that all fellow Africans are welcome in South Africa and that the attacks are simply criminal, provides a sobering counterpoint to their chants.

\section{Relational readings as strategy for grappling with new Africanicities}

In the light of these two (admittedly very spectacular) examples, charting a way forward through acknowledging 'the chaotic trajectories of our diasporic histories' referred to in the summation of Ndebele's The Cry of Winnie Mandela might thus seem impossibly utopian, as notions of a 'real', lived national identity remain elusive for the foreseeable future. But while the chaotic entanglements of diaspora space and the juxtapositions of difference within diaspora identity are generally more struggled with than embraced, at least they are engaged with in the writings, performances and readings presented here, as in 'a flick of a tongue' referred to in the epigraph, that nevertheless enlarges the world. As noted earlier, this should alert us to the scope for relational readings of differently mediated texts in ways which have some synergies with Jacobs' discussion of a dialogue between writerly and painterly texts within a work. In fact, such relational readings, while not providing answers to the unanswered questions Jacobs raises about the conceptual ambit of the term diaspora as a frame for reading such diverse works, nevertheless suggest how useful an open-ended application of diaspora can be. For instance, reading chapters and texts 'relationally' shows how a particular diasporic lens appropriated for one text (Stuart Halls' discussion of difference within identity and creole subjectivity as applied to Joubert's Isobelle's Journey) can be even more productively applied to other texts (such as Wicomb's David's Story, Playing in the Light, and especially October, given the body of scholarship that situates Wicomb's work in relation to crosscontinental diasporic, especially Caribbean, frameworks which explore creole subjectivities). Similarly productive is widening the scope of narrating and performing diasporic South African identities to include the 'new Africanicity' referred to earlier and extending studies of South African diasporic identities to include what Omotoso describes as 'the story of the Non-Southern African in South Africa' (in Fasselt 2015:235). At the same time, I am wondering whether one could see the intertextuality characterising some of the work of a generation of younger writers (such as the playwright, Paul Grootboom), as an alternative permutation of a diasporic consciousness, albeit also a symptom of globalisation? Ending with yet another question, could we begin to think of yet another kind of diaspora consciousness, less bound to geographic location than to a sense of identifying with elsewhere in ways that speak to being here.

\section{Acknowledgements Competing interests}

The author declares that she has no financial or personal relationships that may have inappropriately influenced her in writing this article.

\section{References}

Ballentine, C., 2000, 'Joseph Shabalala: African composer', in S. Nuttall \& C. Michae (eds.), Senses of culture, Oxford University Press, Oxford, pp. 231-255.

Christian, L., 2005, 'Beyond Black Atlantic and postcolonial studies: The South African differences of Sol Plaatje and Peter Abrahams', in A. Loomba, S. Kaul, M. Bunzai, A. Burton \& J. Esty (eds.), Postcolonial studies and beyond, pp. 252-271, Permanent Black, New Dehli.

Cliff, M., 1991, 'Michelle Cliff', in P. Mariani (ed.), Critical fictions: The politics of imaginative writing, pp. 66-68, Bay Press, Seattle, WA.

Fasselt, R., 2015, “I'm not Afropolitan - I'm of the continent": A conversation with Yewande Omotoso', The Journal of Commonwealth Literature 50(2), 231-246. https://doi.org/10.1177/0021989414552922

Fleishman, M. (ed.), 2015, Performing migrancy and mobility in Africa: The cape of flows, Palgrave Macmillan, London.

Flockemann, M., 2001, 'Fictions of home and (Un)belonging: Diasporan frameworks in Michelle Cliff's Abeng and Zoe Wicomb's "Journey to the Gifberge", Alternation 8(1), 116-133

Flockemann, M., Ngara, K., Roberts, W. \& Castle, A.J., 2010, 'The everyday experience of xenophobia. Performing the crossing from Zimbabwe to South Africa', Critical Arts 24(2), 245-259. https://doi.org/10.1080/02560041003786516

Frenkel, R., 2010, 'Writing South Africa in Diaspora: Imram Coovadia's the wedding', in J. Singh \& R. Chetty (eds.), Indian writers transnationalisms and diasporas', pp. 123-144, Peter Lang, New York.

Global forced displacements hits record high, viewed 23 July 2016, from http://www. unhcr.org/news/latest/2016/6/5763b65a4/global-forced-displacement-hitsrecord-high.html

Gunesekera, R., 1996, Reef, Granta, London.

Jacobs, J.U., 2016, Diaspora and identity in South African fiction, University of KwaZulu-Natal Press, Pietermaritzburg.

Jamal, A. \& Moorthy, S. (eds.), 2010, Indian Ocean studies: Cultural, social, and political perspectives, Routledge, London.

Kaarsholm, P., 2012, 'Diaspora or transnational citizens? Indian Ocean networks and changing multiculturalism in South Africa', Social Dynamics, Special Issue: Mobility, Diasporas and Transnational Imaginings in the Indian Ocean 38, 454-466.

Krueger, A., 2016, 'The implacable grandeur of the stranger: Ruminations on fear and familiarity in Die Vreemdeling (The Stranger) (2010)', in M. Lewis \& A. Krueger (eds.), Magnet theatre: Three decades of making space, pp. 111-126, Intellect \& Unisa University Press, Bristol.

Nasta, S. (ed.), 1992, Motherlands: Black women writing from Africa, the Caribbean and South Asia, Rutgers University Press, New Dehli.

Omotoso, Y., 2015, “'In my storytelling I privilege the micro!" An interview with Yewande Omotoso', viewed 23 September 2016, from http://shortstorydayafrica. org/news/in-my-storytelling-i-privilege-the-micro-an-interview-with-yewandeomotoso

Pinto, S., 2013, Difficult diasporas: The transnational feminist aesthetic of the Black Atlantic, New York University Press, New York.

Raiskin, J., 1996, Snow on the cane fields: Women's writing and creole subjectivity, University Minnesota Press, Minneapolis, MN.

Rastogi, P., 2008, Afrindian fictions: Desire, race and national desire in South Africa Ohio State University Press, Athens, $\mathrm{OH}$.

Reznek, J., Fleishman, M., Yisa, F. \& Marek, F., 2012, The Magnet Theatre 'migration' plays, Junkets Publisher, Cape Town.

Richards, C., 2002, 'Nationalism and the development of identity in postcolonial fiction: Zoë Wicomb and Michelle Cliff', Research in African Literature 36(1), 20-33.

Samuelson, M. \& Viljoen, S. (eds.), 2007, 'Oceanic worlds/bordered worlds', Socia Dynamics 33(2), 1-2.

Tsagarousianou, R., 2004, 'Re-thinking the concept of diaspora: Mobility, connectivity and communication in a globalised world', Westminster Papers in Communication and Culture 1(1), 52-65.

Van Graan, M., 2016. Pay Back the Curry, Unpublished play script, Cape Town.

White, P, 1995, 'Geography, Literature and Migration', in R. King, J. Connell and P. White (eds), Writing Across Worlds, pp. 1-9, Routledge, New York. 